\title{
Assessment of Groundwater Quality Using Water Quality Index and Geographic Information System in Kumbotso Local Government Area, Kano State, Nigeria
}

\author{
Saidu A. A. ${ }^{1}$, Danazumi S. ${ }^{1}$ and Hamza S. M. ${ }^{2}$ \\ ${ }^{1,2}$ Department of Civil Engineering, Bayero University, Kano, Kano State, Nigeria \\ ${ }^{2}$ Department of Civil Engineering, Hussaini Adamu Federal Polytechnic, Kazaure, Jigawa State, Nigeria \\ Corresponding Author: *aasaidu89@gmail.com
}

https://doi.org/10.36263/nijest.2021.02.0318

\begin{abstract}
Water managers are faced with issues of groundwater resources management in dry land environments characterized by increasing population growth and prolonged dry period. Pollution of such resources has become a problem of notable importance in many arid and semi-arid environments of the developing countries. Unplanned urbanization; industrialization coupled with an increase in agricultural expansion has adversely affected groundwater quality. This study provides an overview of the status of groundwater quality in Kumbotso L.G.A using Water Quality Index. Physico-chemical parameters of $\mathrm{pH}$, total dissolved solids, total hardness, magnesium, chloride, nitrate, calcium, and sulphate were measured from 12 groundwater samples. The results of the analysis were compared to the WHO standards to ascertain conformity with the guidelines. The Geographic Information System (GIS) was employed for mapping the distribution of various quality parameters as well as the overall groundwater quality condition. The overall map produced shows that $53.42 \mathrm{~km}^{2}$ of the study area representing $33.81 \%$ were of excellent quality while $104.58 \mathrm{~km}^{2}$ representing $66.19 \%$ of the area was found to be of good quality. Thus, a GIS based map developed can be a useful practical tool by water managers, policymakers and concerned communities in taking strategic decisions towards effective management of groundwater in the study area.
\end{abstract}

Keywords: Groundwater sources, Pollution, Water Quality Index, Physico-chemical parameters, Geographical Information System

\subsection{Introduction}

Human survival on the earth surface as well as sustainable development and security depends on water (Griggs et al., 2013). As such water is primarily used for domestic, industrial and agricultural activities and is necessary for the sustainable economic development of an area (Pritchard et al., 2008). The increase in the water demand is a result of population growth and economic development especially the groundwater resources (Roy et al., 2020). The development of which has a negative impact on groundwater quality and quantity (Hemamalini et al., 2017).

Concerns about surface water shortage and its deterioration are reasons behind excessive exploration and exploitation of groundwater in many arid and semi-arid environments of the developing countries (Thirumalaivasan et al., 2003; Zingoni et al., 2005). However in Nigeria particularly in semi-arid environments of Northern Nigeria surface water deterioration, inadequate water provision by authorities concerned, the effect of climate change and in addition to population growth which has forced many people to rely on groundwater sources for water use (Akujieze et al., 2003). In Kano, the availability of surface water sources are not encouraging and where available it is polluted to a considerable degree (Bichi, 2000; Akan et al., 2009; Dan'azumi and Bichi, 2010; Dike et al., 2013). Thus, making groundwater sources a necessary alternative for water supply in such regions. 
Anthropogenic activities are the major factors that influence the pollution of groundwater resources in Nigeria (Galadima et al., 2011). Because of the importance attached to these resources globally, their pollution issues have enticed attention from researchers which makes their quality a topic of relative importance in the area of groundwater resources management (Pradhan, 2009; Shirazi et al.; 2012; Manap et al., 2013). Consequently describing groundwater quality condition through the use of the Water Quality Index (WQI) that integrate multiple parameters into a unique index depicting quality status in term of excellent, good, or poor is paramount because it makes quality information simple and easily interpretable (Mitra et al., 2006; Varnosfaderany et al., 2009; Sharma and Patel, 2010). Many scholars have adopted the technique of WQI and GIS to model the distribution of groundwater quality in different parts of the world and achieved reliable results (Bairu et al., 2013; Krishan et al., 2016; Ambiga, 2016; Hamza et al., 2017; Al-Musawi et al., 2018). This proved such an approach to be a more informative means of assessing groundwater quality (Jasmin and Mallikarjuna, 2014).

Kano is among the most populous and industrialized cities in Nigeria and this implies that anthropogenic activities are probably responsible for groundwater pollution in such regions (Hamza et al., 2017). Growing urban and industrial areas in Kano lead to an increase in consumption of freshwater in these regions and indiscriminate disposal of hazardous sludge, solid wastes, discharge of industrial effluent, domestic sewage and municipal wastewater into freshwater cause groundwater pollution (Khan et al., 2012, 2013; Panigrahi et al., 2012; Allamin, 2015). Monitoring agencies like the Kano State Environmental Protection Agency have attempted to manage these causes of groundwater pollution but have been unsuccessful (Egwuonwu et al., 2011). Thus, making such a global issue a topic of considerable importance in the region and Nigeria at large (Adelana, 2004). Given the aforementioned, this study applied WQI and GIS to assess groundwater quality status for drinking in the Kumbotso Local Government Area of Kano State, Nigeria.

\subsection{Methodology}

\subsection{Study location}

Kumbotso Local Government Area is one of the 44 local government areas located between latitude $11^{\circ} 53^{\prime} 17^{\prime} \mathrm{N}$ and longitude $8^{0} 30^{\prime} 10^{\prime \prime} \mathrm{E}$ in the Northwestern State of Kano, Nigeria with an area coverage of $158 \mathrm{~km}^{2}$ as shown in Figure 1 .

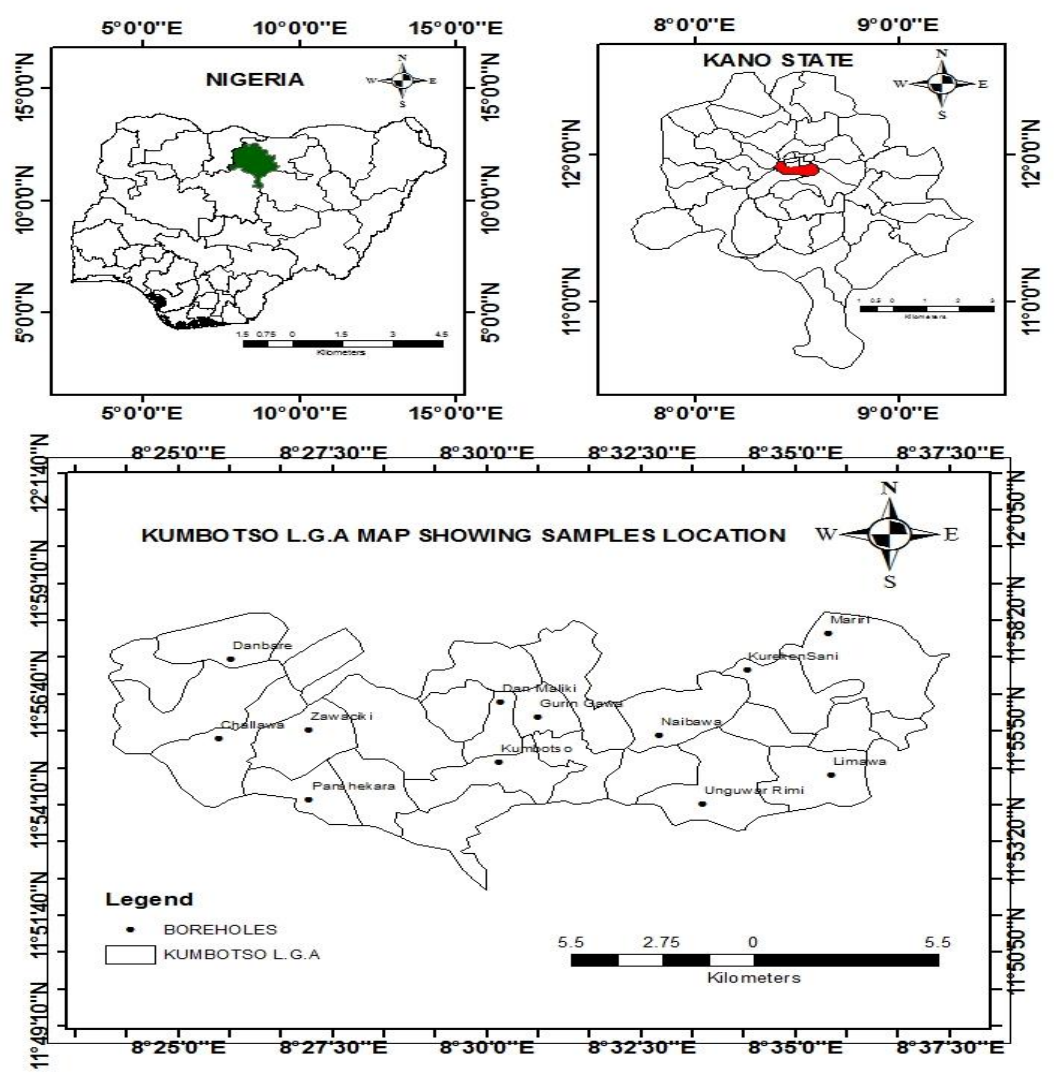

Figure 1: Map of study area showing samples location 


\subsection{Methods}

Both spatial and non-spatial data were utilized in this study. The spatial data used was data corresponding to the administrative boundary of Nigeria in shape file format downloaded from DIVA-GIS (http://www.divagis.com). The shape files of Kano State and that of the study area were masked down in Arc GIS software. Localization of each borehole was recorded using (GPS) while the non-spatial data include analysis of physicochemical parameters at Kano State Water Board, Challawa Water Quality Laboratory Kano. A total 12 groundwater samples from different boreholes were collected in 11 wards within the study location as described in Table 1.

Table 1: Description of Groundwater Samples Sites.

\begin{tabular}{llllc}
\hline No. & Longitude & Latitude & Description & Sites ID No \\
\hline 1 & 8.5583 & 11.9030 & Unguwar Rimi & A1 \\
2 & 8.5033 & 11.9189 & Kumbotso & A2 \\
3 & 8.5931 & 11.9139 & Limawa & A3 \\
4 & 8.4278 & 11.9278 & Challawa & A4 \\
5 & 8.5924 & 11.9673 & Mariri & A5 \\
6 & 8.5704 & 11.9537 & Kureken Sani & A6 \\
7 & 8.5467 & 11.9289 & Naibawa & A7 \\
8 & 8.5138 & 11.9358 & Gurin Gawa & A8 \\
9 & 8.5038 & 11.9414 & Dan Maliki & A9 \\
10 & 8.4522 & 11.9049 & Panshekara & A10 \\
11 & 8.4522 & 11.9311 & Zawaciki & A11 \\
12 & 8.4310 & 11.9579 & Danbare & A12 \\
\hline
\end{tabular}

All the samples were analyzed in the laboratory for the various quality parameters using standard methods as shown in Table 2 (APHA, 2005). The laboratory analysis results and secondary data were compared to ascertain conformity with the international guidelines as shown in Table 3 (WHO, 2011). A Geographic Information System was employed to map and characterize the distribution of various quality parameters as shown in Figures 2 to 11.

Table 2: Analytical Methods Adopted for Physico-chemical Analysis

\begin{tabular}{lll}
\hline No. & Quality Parameters & Analytical Methods \\
\hline 1 & $\mathrm{pH}$ & Digital pH meter \\
2 & Total Dissolved Solids & Gravimetric Method \\
3 & Total Hardness & EDTA-Titrimetry Method \\
4 & Magnesium & Spectrophotometry Method \\
5 & Calcium & Flame Photometric Method \\
6 & Sulphates & Turbidimetric Method \\
7 & Chlorides & Mohr'sTitrimetry Method \\
8 & Nitrates & Spectrophotometry Method \\
\hline
\end{tabular}

"Weighted Arithmetic Method" by (Cude, 2001) was implemented for evaluating groundwater quality index for all samples as shown in Equation 1,2, 3 and 4 the results were also shown in Table 4.

$W Q I=\sum_{i=1}^{n} Q_{n} W_{n} / \sum_{i=1}^{n} W_{n}$
$Q_{n}=100\left[\left(V_{n}-V_{i}\right) /\left(S_{n}-V_{i}\right)\right]$

Where $\mathrm{Q}_{\mathrm{n}}=$ quality rating for $\mathrm{n}^{\text {th }}$ parameter

$\mathrm{V}_{\mathrm{n}}=$ Estimated value of the $\mathrm{n}^{\text {th }}$ parameter at a given sampling station

$\mathrm{S}_{\mathrm{n}}=$ Standard permissible value of the $\mathrm{n}^{\text {th }}$ parameter

$\mathrm{V}_{\mathrm{i}}=$ Ideal value of $\mathrm{n}^{\text {th }}$ in pure water (i.e 0 for all parameters except $\mathrm{pH}$ which is 7).

$W_{n}=K / S_{n}$

Where $\mathrm{W}_{\mathrm{n}}=$ unit weight of the $\mathrm{n}^{\text {th }}$ parameters and $\mathrm{K}$ is the proportionality constant given by 
$K=\frac{1}{\sum_{i=1}^{n} 1 / S_{n}}$

The water quality index results were utilized in creating an overall map showing spatial distribution of groundwater quality status within the study location using Arc GIS 10.5 as shown in Figure 11.

\subsection{Results and Discussion}

The physico-chemical characteristics of samples collected from various locations in the study area are displayed in Table 3 and results were compared with WHO standards and found to be within the permissible limits of WHO (2011).

Table 3: Measured Values of Groundwater Quality Parameters and World Health Organization Guidelines-WHO, 2011.

\begin{tabular}{lccccccccccccc}
\hline Parameters & A1 & A2 & A3 & A4 & A5 & A6 & A7 & A8 & A9 & A10 & A11 & A12 & WHO \\
\hline $\mathrm{pH}$ & 8.0 & 6.8 & 7.9 & 7.8 & 7.5 & 6.5 & 8.0 & 6.7 & 6.9 & 6.6 & 6.5 & 6.8 & $6.5-8.5$ \\
TDS mg/l & 193 & 233 & 225 & 222 & 227 & 114 & 187 & 227 & 240 & 318 & 233 & 190 & 500 \\
Hardness mg/l & 84 & 81 & 122 & 68 & 93 & 74 & 118 & 88 & 70 & 105 & 123 & 108 & 300 \\
Magnesium mg/l & 15 & 15 & 18 & 13 & 16 & 14 & 19 & 16 & 15 & 19 & 20 & 18 & 50 \\
Calcium mg/l-1 & 10 & 9 & 16 & 12 & 18 & 14 & 18 & 14 & 12 & 16 & 20 & 20 & 75 \\
Sulphates mg/l & 3.8 & 5.4 & 3 & 2.5 & 3.5 & 3.5 & 4.8 & 4.1 & 4.8 & 9.2 & 3.3 & 6.1 & 250 \\
Chlorides mg/l-1 $^{-1}$ & 35 & 46 & 63 & 42 & 77 & 35 & 58 & 45 & 37 & 87 & 76 & 59 & 250 \\
Nitrates mg/l & 6 & 8 & 4 & 12 & 3 & 7 & 2 & 5 & 5 & 1 & 1 & 1 & 45 \\
\hline
\end{tabular}

The spatial distribution of various physico-chemical parameters in Figure 2 shows that $\mathrm{pH}$ concentrations are in the range 6.5 to 8.0 which is within the permissible limit but groundwater in south-western, south-eastern and north-eastern part of the area are slightly alkaline (WHO, 2011). The distribution of TDS in Figure 3 ranged from minimum of $114 \mathrm{mgl}^{-1}$ to maximum of $318 \mathrm{mgl}^{-1}$ and was below the permissible limits of $500 \mathrm{mgl}^{-1}$, but TDS level at the south-western part was slightly high (WHO, 2011). The spatial distribution of hardness analyzed ranges from $68-123 \mathrm{mgl}^{-1}$ as shown in Figure 4 and is in accordance with the permissible limit of $300 \mathrm{mgl}^{-1}$ for drinking water (WHO, 2011). Even though the concentration of hardness is slightly high in some cases, it poses no threat to groundwater quality. Figure 5 demonstrates thematic map of magnesium level in the study area and reveals magnesium concentration in groundwater varies from minimum of $13 \mathrm{mgl}^{-1}$ to maximum of $20 \mathrm{mgl}^{-1}$ and within the permissible limit of $50 \mathrm{mgl}^{-1}$ (WHO, 2011). Spatial distribution of calcium in Figure 6 varies from 9 to $20 \mathrm{mgl}^{-1}$ and falls within the permissible limits of $75 \mathrm{mgl}^{-1}$ (WHO, 2011). Sulphates exist in nearly all natural water and distribution of sulphate as shown in Figure 7 varies from 2.5 to $9.2 \mathrm{mgl}^{-1}$ and falls below the permissible limits according to (WHO, 2011). Distribution of chloride as shown in Figure 8 indicates a fluctuation between 35 to $87 \mathrm{mgl}^{-1}$ and falls below the permissible level recommended by (WHO, 2011). Nitrate distribution in Figure 9 shows values ranging from 1 to $12 \mathrm{mgl}^{-1}$ and fall below the permissible limits of $45 \mathrm{mgl}^{-1}$ by WHO (2011) for potable water. However, slightly high levels of nitrate in south-western part may be attributed to leaching from waste disposal, sanitary landfill and anthropogenic activity involving nitrate pollution which was also observed by (Chapman, 1996). 


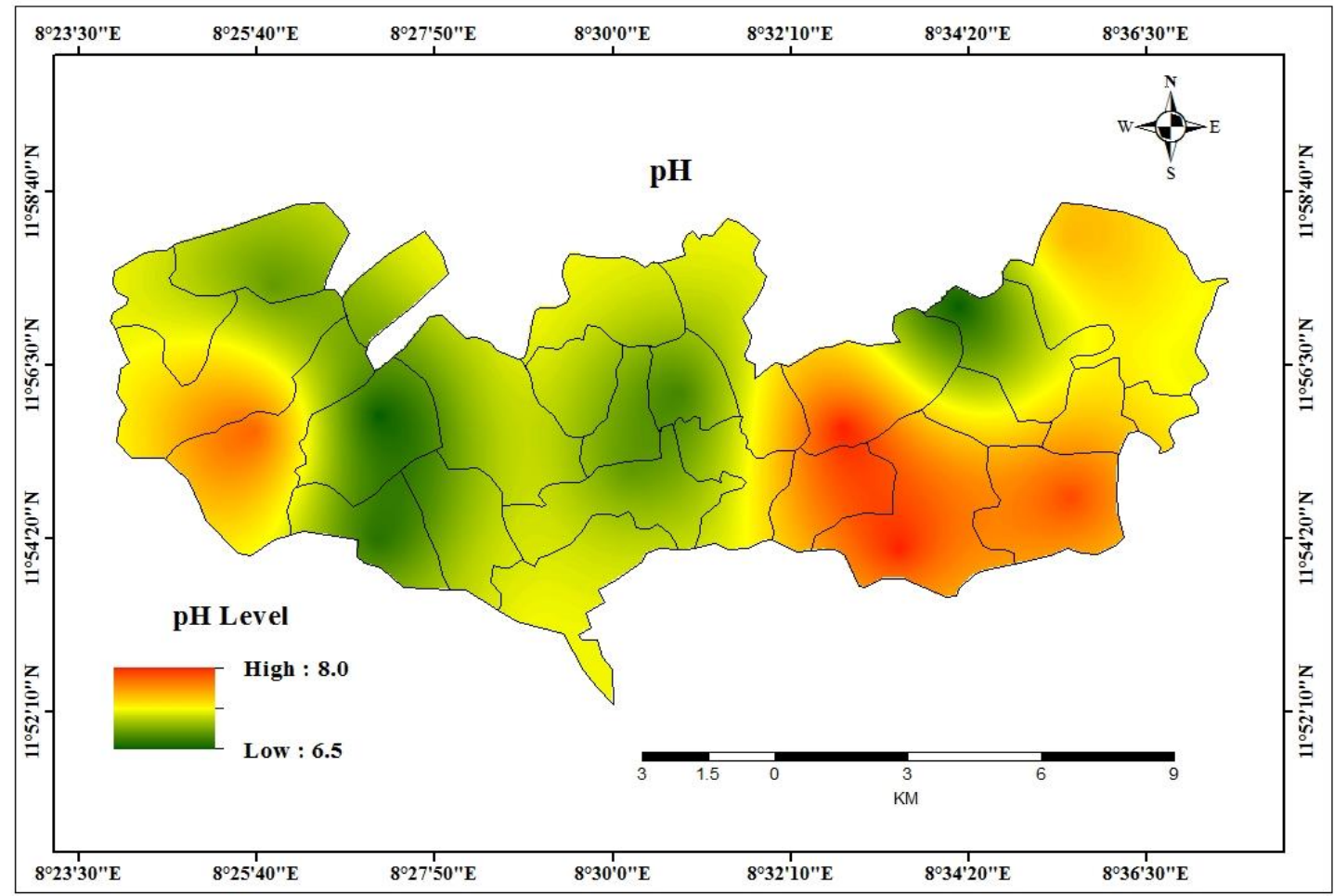

Figure 2: Map of interpolated $\mathrm{pH}$

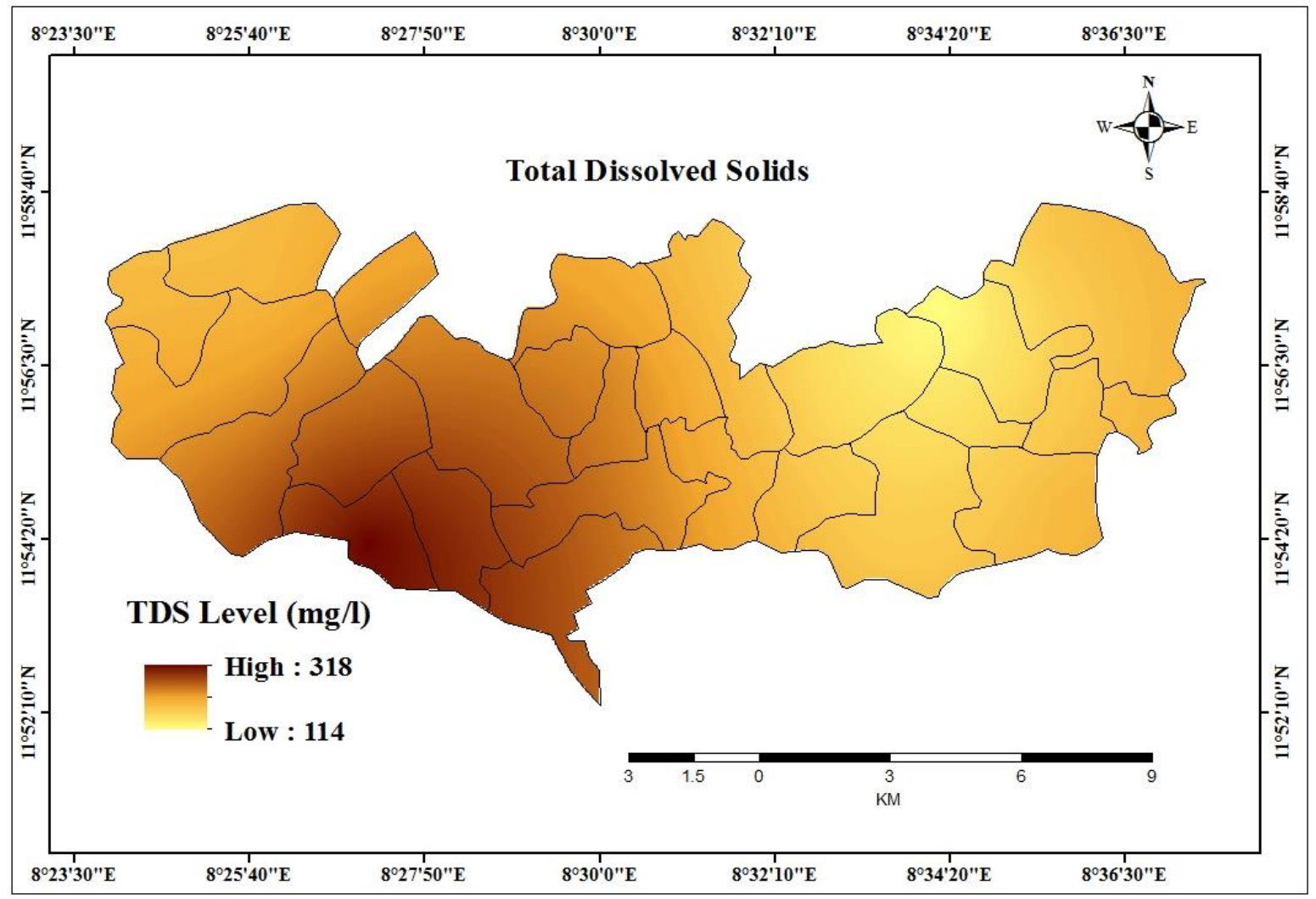

Figure 3: Map of interpolated total dissolved solids 


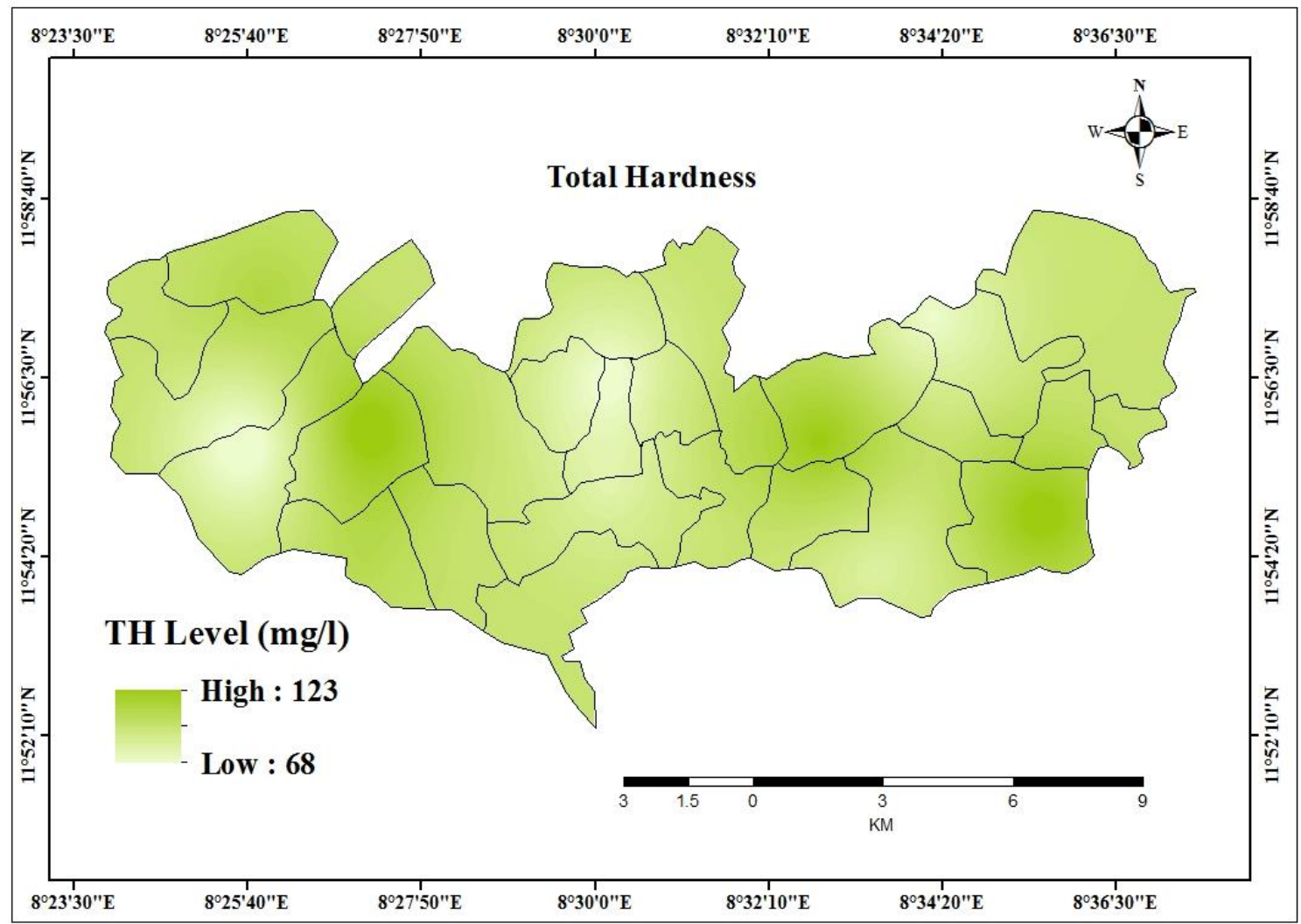

Figure 4: Map of interpolated total hardness

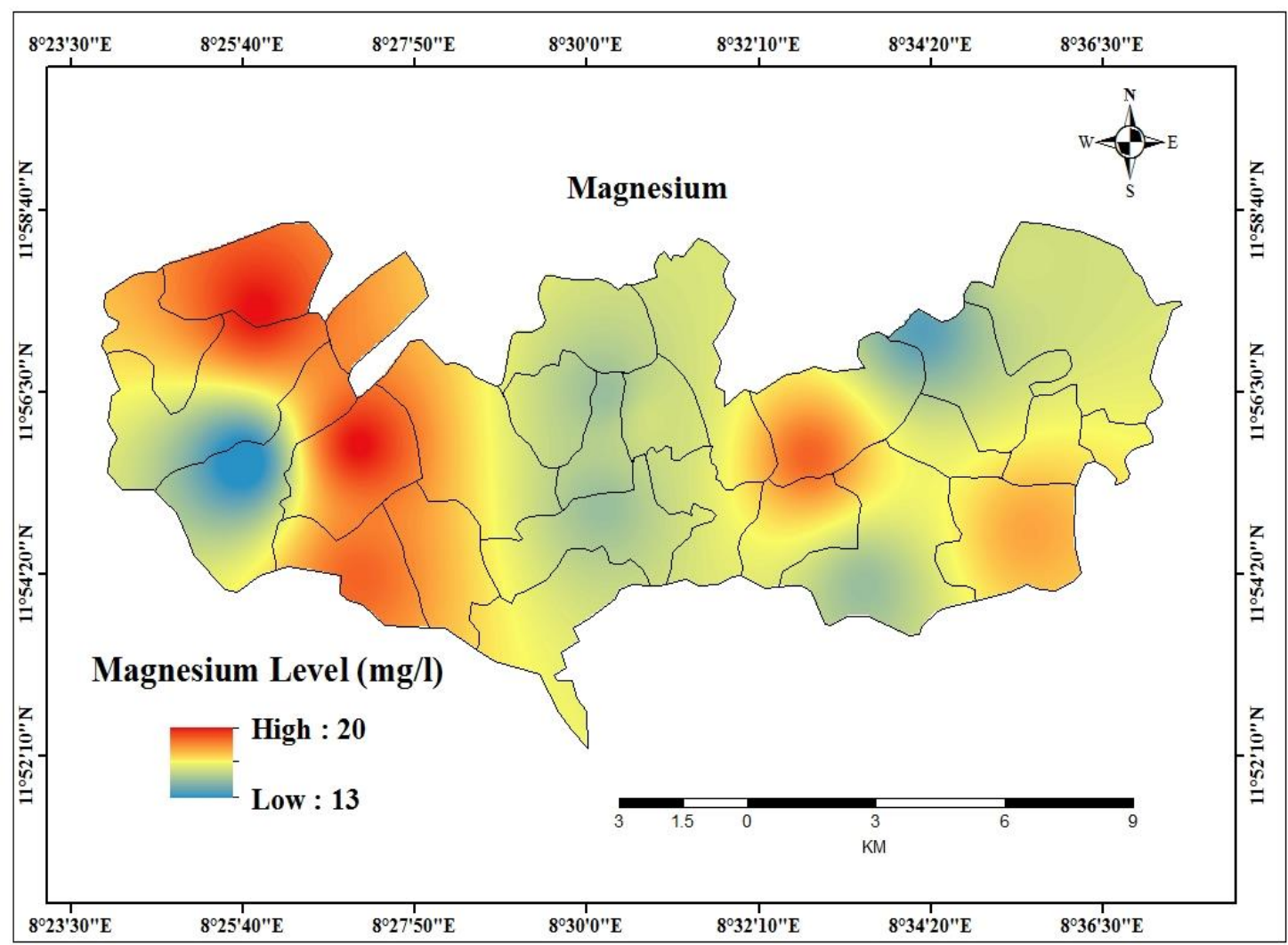

Figure 5: Map of interpolated magnesium 


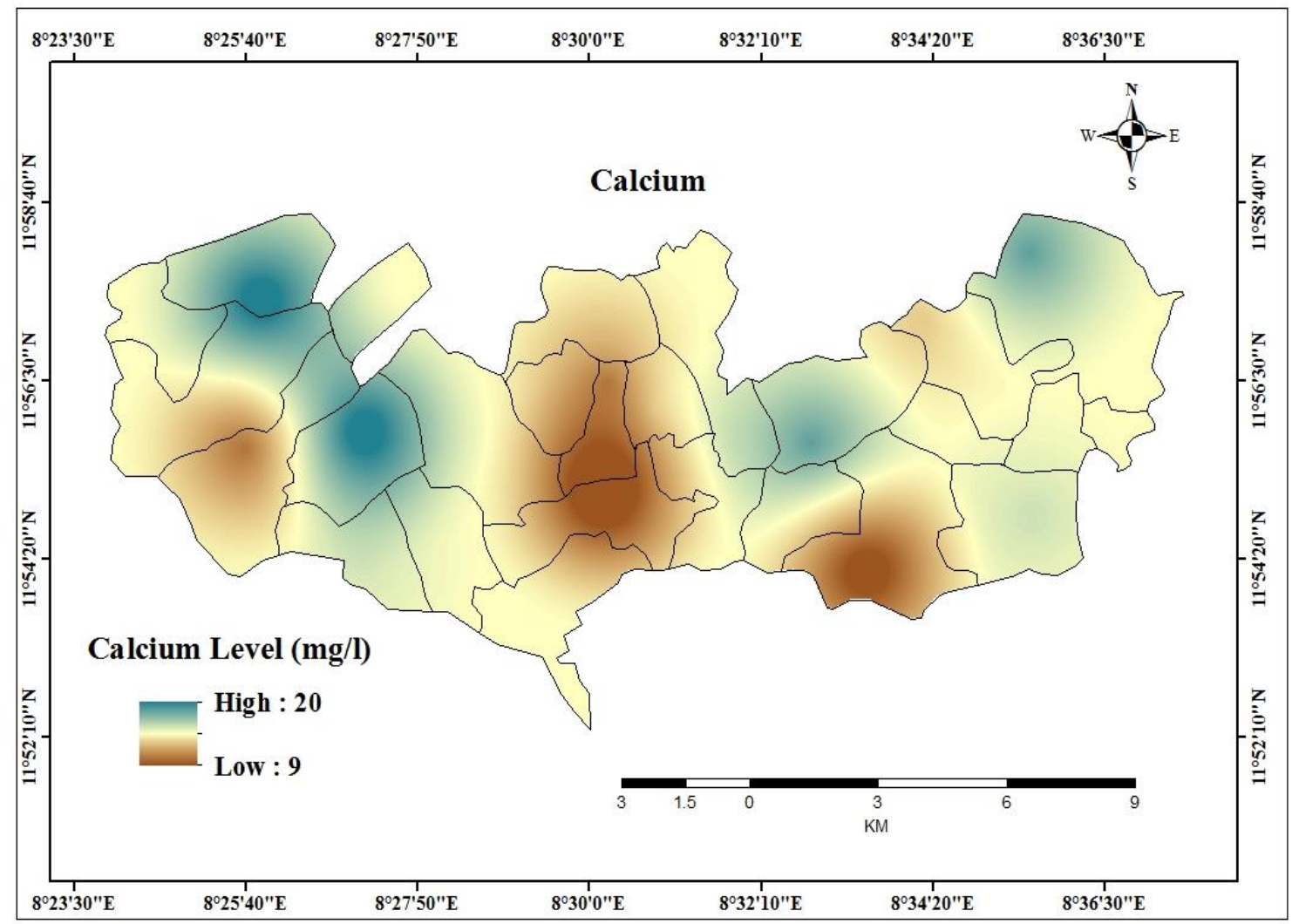

Figure 6: Map of interpolated calcium

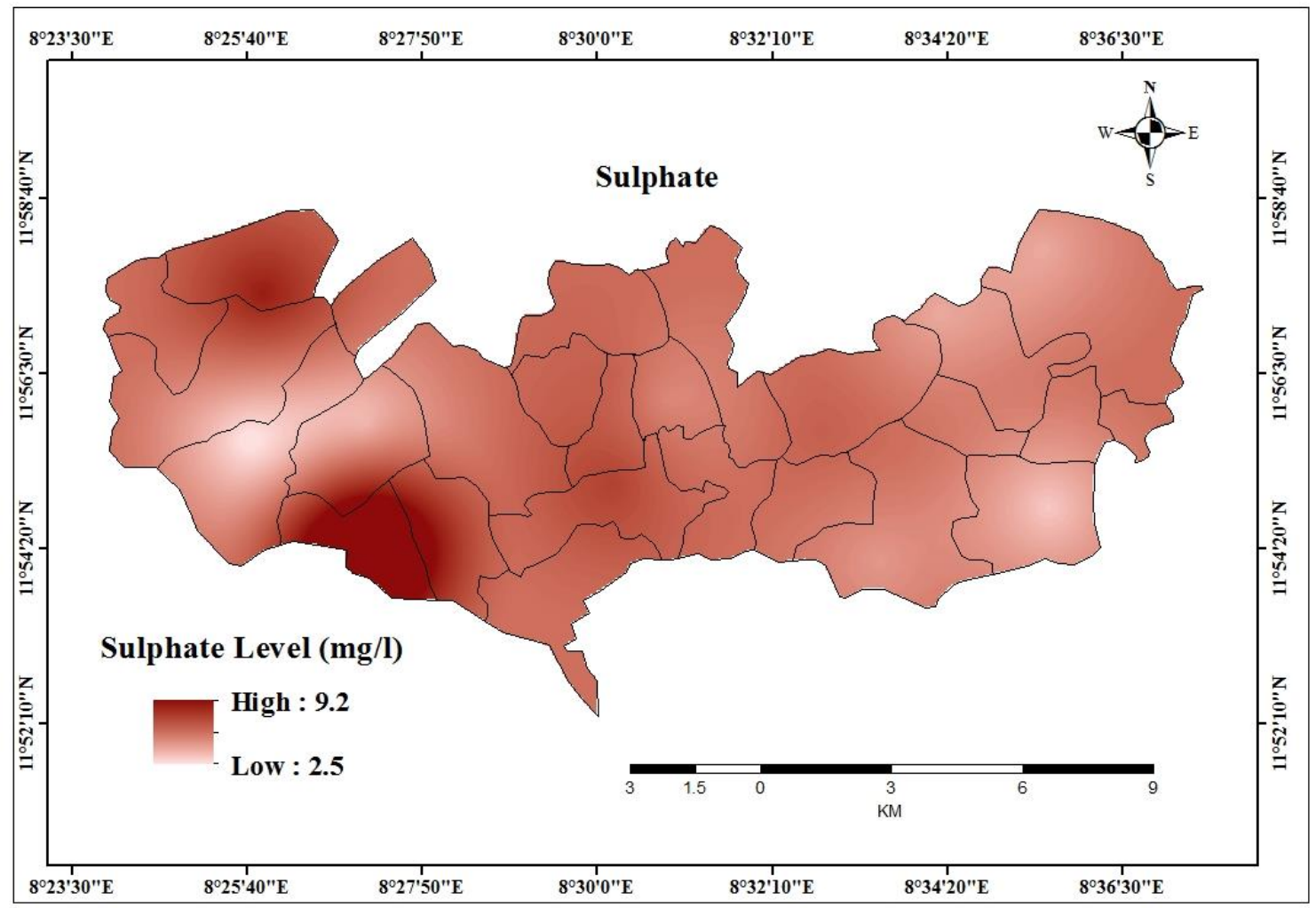

Figure 7: Map of interpolated sulphate 


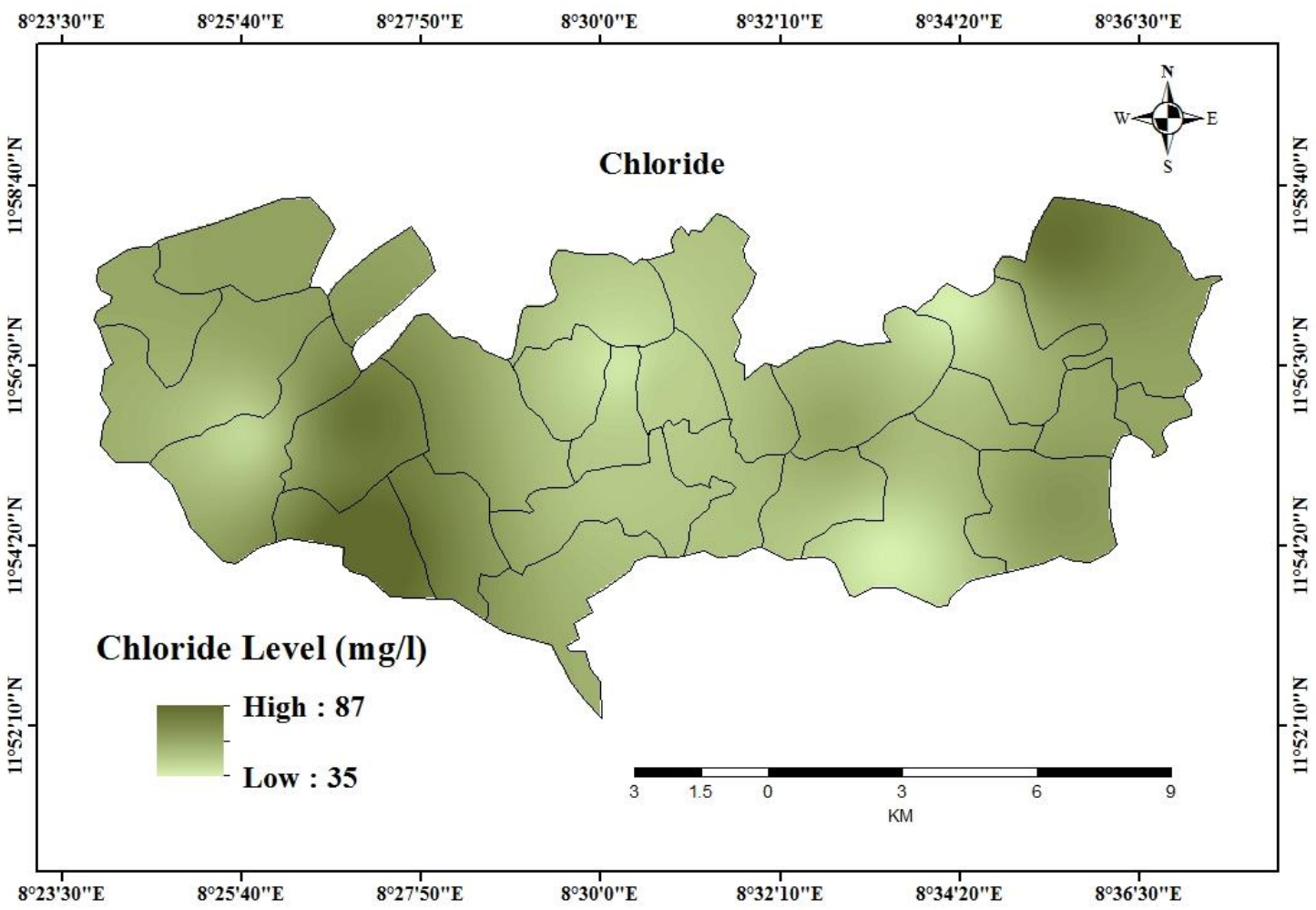

Figure 8: Map of interpolated chloride

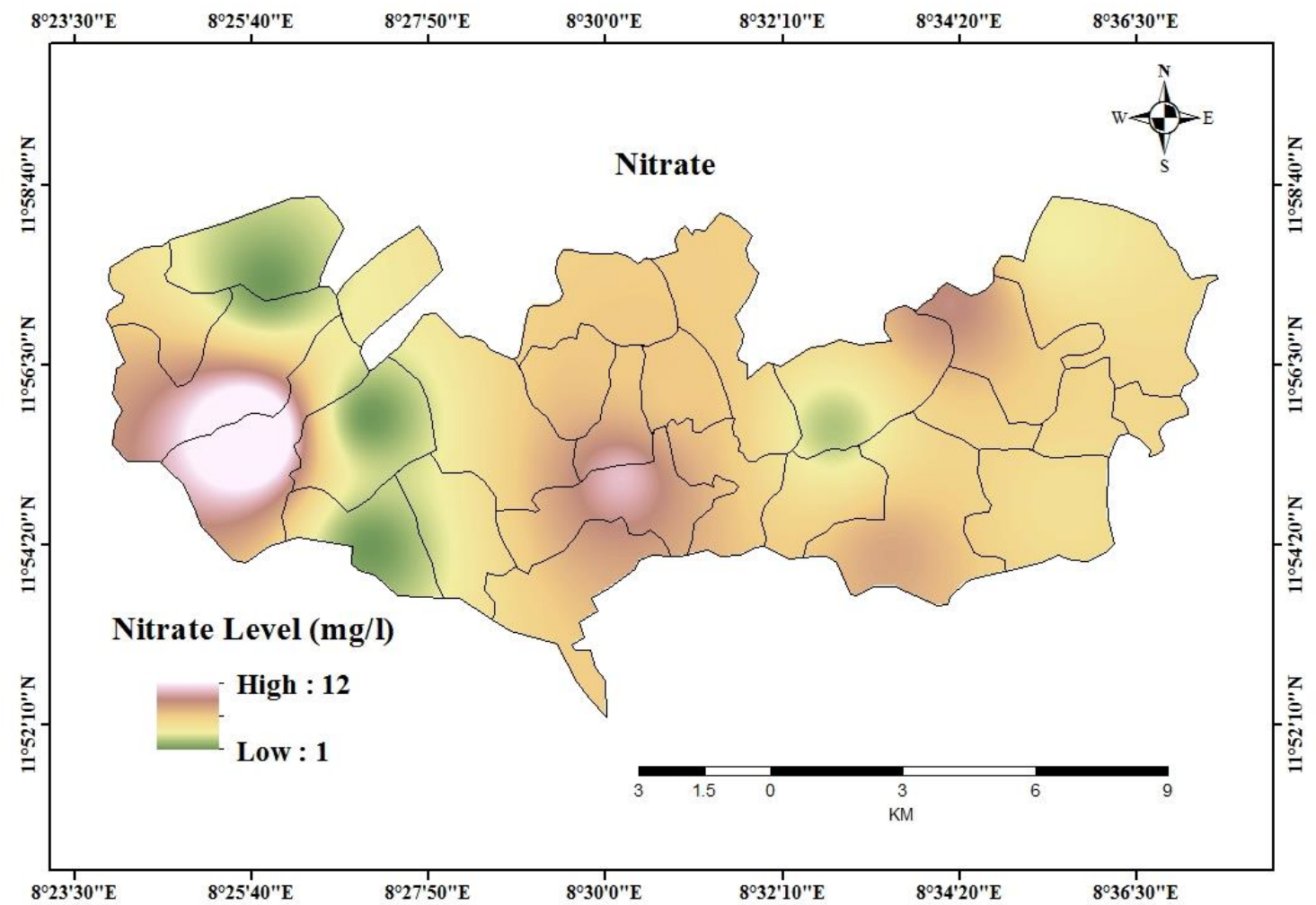

Figure 9: Map of interpolated nitrate

The calculations of WQI presented in Table 4 and the distribution of the groundwater quality in Figure 10 shows values between 11.19 to 49.06 and according to Table 5 of WQI classification proposed by Chaterjee and Raziuddin (2002), $53.42 \mathrm{~km}^{2}$ of the study area representing $33.81 \%$ of total 
area was classified to be in excellent quality and the rest of $104.58 \mathrm{~km}^{2}$ representing $66.19 \%$ of the total area was found to be in a good water quality class as shown in Figure 11.

Table 4: Calculated values of WQI for various groundwater samples

\begin{tabular}{|c|c|c|c|c|c|c|c|c|c|c|c|c|c|}
\hline Parameters & $\begin{array}{c}\mathrm{A} 1 \\
\mathrm{Q}_{\mathrm{n}} \mathrm{W}_{\mathrm{n}}\end{array}$ & $\begin{array}{c}\mathrm{A} 2 \\
\mathrm{Q}_{\mathrm{n}} \mathrm{W}_{\mathrm{n}}\end{array}$ & $\begin{array}{c}\mathrm{A} 3 \\
\mathrm{Q}_{\mathrm{n}} \mathrm{W}_{\mathrm{n}}\end{array}$ & $\begin{array}{l}\mathrm{A} 4 \\
\mathrm{Q}_{\mathrm{n}} \mathrm{W}_{\mathrm{n}}\end{array}$ & $\begin{array}{l}\mathrm{A} 5 \\
\mathrm{Q}_{\mathrm{n}} \mathrm{W}_{\mathrm{n}}\end{array}$ & $\begin{array}{l}\mathrm{A} 6 \\
\mathrm{Q}_{\mathrm{n}} \mathrm{W}_{\mathrm{n}}\end{array}$ & $\begin{array}{l}\mathrm{A} 7 \\
\mathrm{Q}_{\mathrm{n}} \mathrm{W}_{\mathrm{n}}\end{array}$ & $\begin{array}{l}\mathrm{A} 8 \\
\mathrm{Q}_{\mathrm{n}} \mathrm{W}_{\mathrm{n}}\end{array}$ & $\begin{array}{l}\mathrm{A} 9 \\
\mathrm{Q}_{\mathrm{n}} \mathrm{W}_{\mathrm{n}}\end{array}$ & $\begin{array}{l}\mathrm{A} 10 \\
\mathrm{Q}_{\mathrm{n}} \mathrm{W}_{\mathrm{n}}\end{array}$ & $\begin{array}{l}\mathrm{A} 11 \\
\mathrm{Q}_{\mathrm{n}} \mathrm{W}_{\mathrm{n}}\end{array}$ & $\begin{array}{c}\mathrm{A} 12 \\
\mathrm{Q}_{\mathrm{n}} \mathrm{W}_{\mathrm{n}} \mathrm{W}_{\mathrm{n}}\end{array}$ & $\mathrm{Un}$ \\
\hline $\mathrm{PH}$ & 42.06 & 8.408 & 37.85 & 33.64 & 21.03 & 21.03 & 37.85 & 12.62 & 4.208 & 16.82 & 21.03 & 8.408 & 0.6308 \\
\hline $\mathrm{TDS}_{\mathrm{mgl}}{ }^{-1}$ & 0.413 & 0.499 & 0.482 & 0.475 & 0.486 & 0.244 & 0.400 & 0.486 & 0.514 & 0.681 & 0.499 & 0.407 & 07 \\
\hline Hardness $\mathrm{mgl}^{-1}$ & 0.501 & 0.483 & 0.728 & 0.227 & 0.555 & 0.442 & 0.704 & 0.525 & 0.418 & 0.627 & 0.734 & 0.645 & 0.0179 \\
\hline Magnesium $\mathrm{mgl}^{-}$ & -13.216 & 3.216 & 3.859 & 2.787 & 3.431 & 3.002 & 4.074 & 3.431 & 3.216 & 4.074 & 4.288 & 3.859 & 0.1072 \\
\hline Calcium mgl ${ }^{-1}$ & 0.953 & 0.858 & 1.525 & 1.144 & 1.715 & 1.335 & 1.716 & 1.335 & 1.144 & 1.525 & 1.907 & 1.907 & 0.0715 \\
\hline es $\mathrm{mgl}^{-1}$ & 0.032 & 0.056 & 0.026 & 0.022 & 0.030 & 0.030 & 0.041 & 0.035 & 0.041 & 0.079 & 0.028 & 0.053 & 0.0215 \\
\hline Chlorides $\mathrm{mgl}^{-1}$ & 0.301 & 0.396 & 0.542 & 0.361 & 0.662 & 0.301 & 0.499 & 0.387 & 0.318 & 0.748 & 0.654 & 0.508 & 0.0215 \\
\hline Nitrates $\mathrm{mgl}^{-1}$ & 1.589 & 2.119 & 1.059 & 3.179 & 0.795 & 1.855 & 0.554 & 1.325 & 1.325 & 0.265 & 0.265 & 0.265 & 0.1192 \\
\hline Sum & 49.07 & 16.04 & 46.07 & 42.34 & 28.71 & 28.24 & 45.84 & 20.15 & 11.19 & 24.82 & 29.41 & 16.05 & 1.0003 \\
\hline WQI & 49.06 & 16.04 & 46.06 & 42.33 & 28.70 & 28.23 & 45.83 & 20.09 & 11.19 & 24.81 & 29.40 & 16.05 & \\
\hline
\end{tabular}

Table 5: Water Quality Index Classification

\begin{tabular}{llc}
\hline WQI & Water quality Status & Grading \\
\hline $0-25$ & Excellent & $\mathrm{A}$ \\
$26-50$ & Good & $\mathrm{B}$ \\
$51-75$ & Poor & $\mathrm{C}$ \\
$76-100$ & Very Poor & $\mathrm{D}$ \\
Above 100 & Unsuitable For Drinking & $\mathrm{E}$ \\
\hline
\end{tabular}

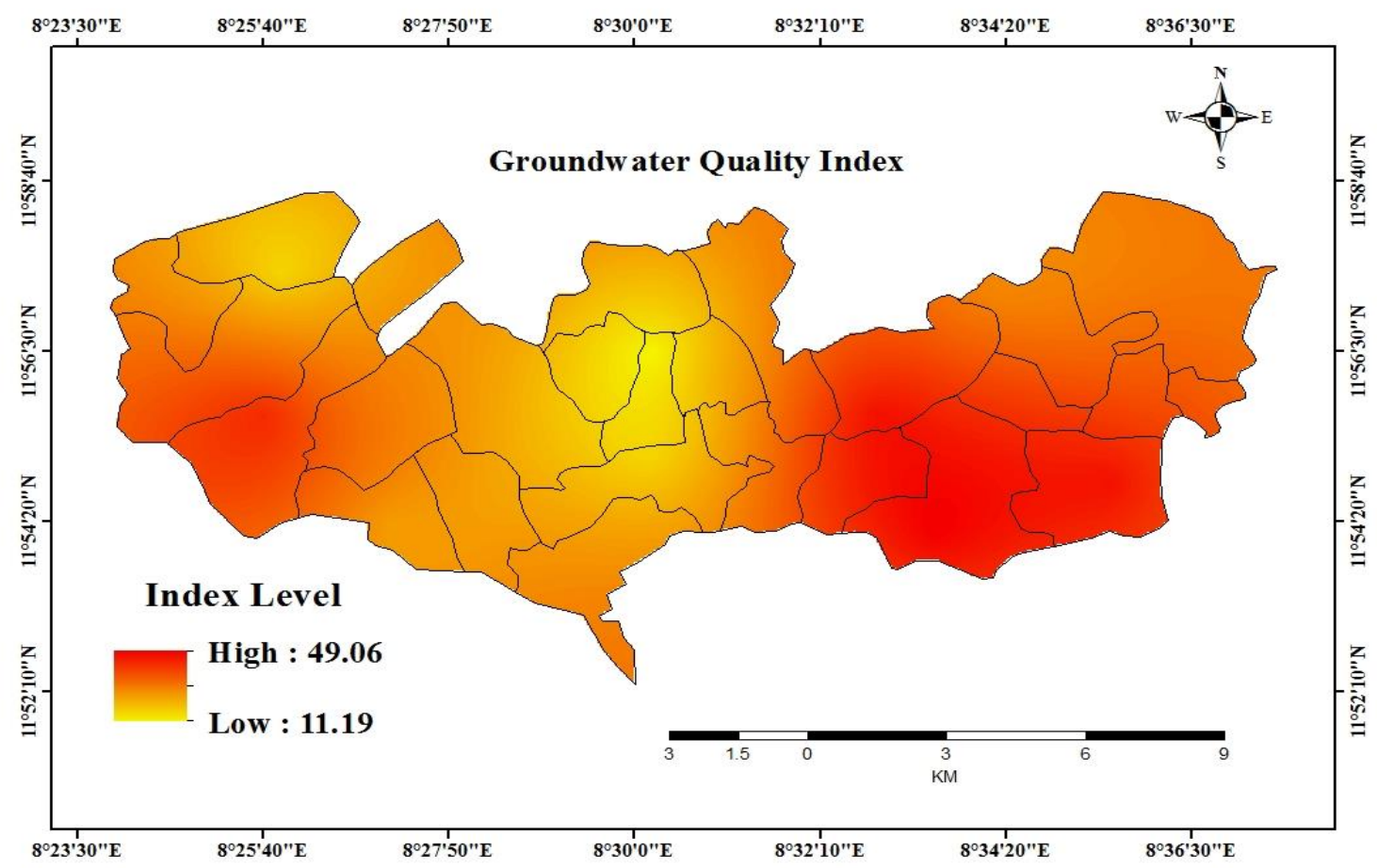

Figure 10: Map of interpolated groundwater quality index 


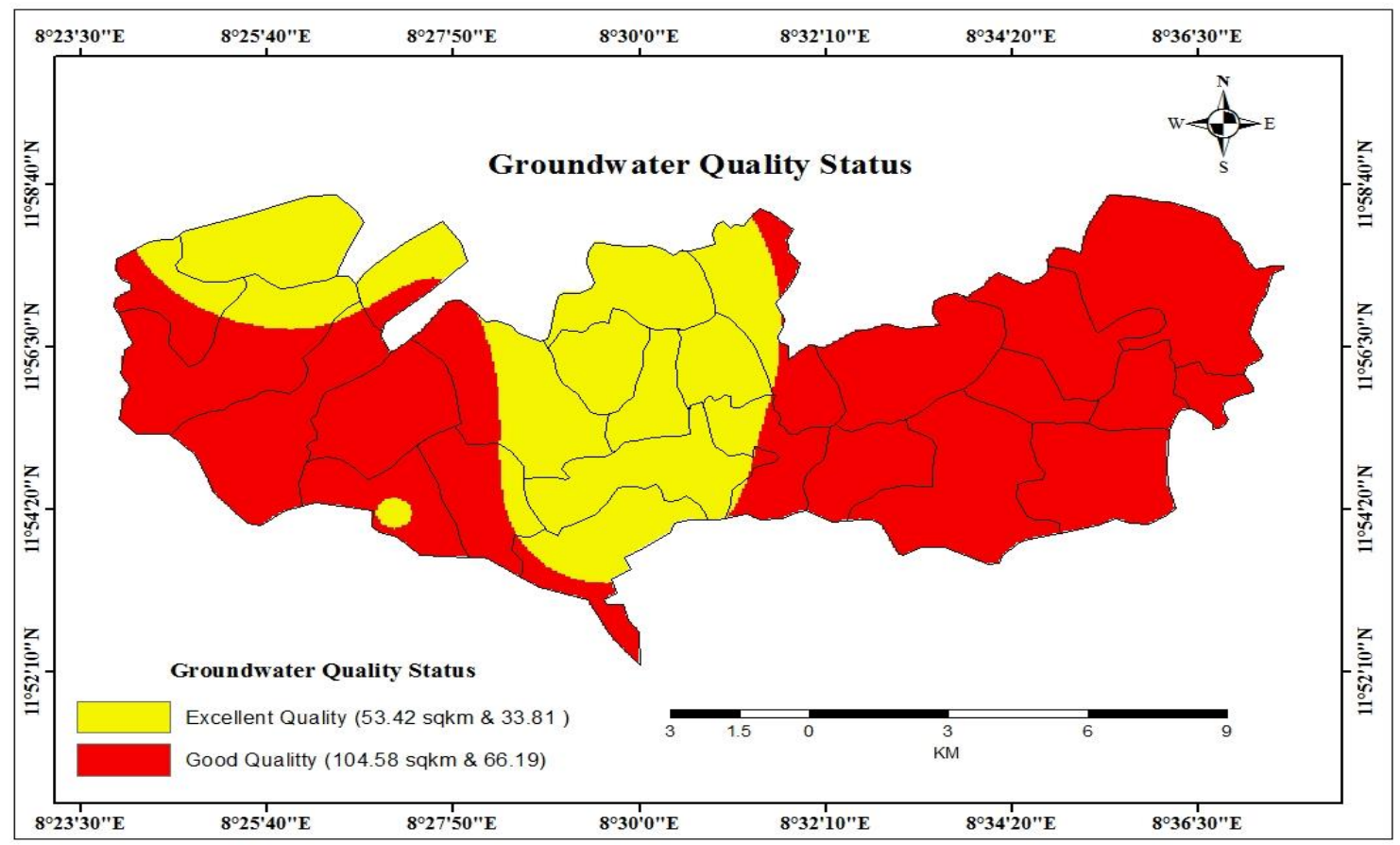

Figure 11: Map of Groundwater Quality Index

\subsection{Conclusions}

Groundwater quality appraisal was carried out in Kumbotso L.G.A, Kano State, Nigeria using GIS and WQI. Geospatial analysis tool of inverse distance weighting was used for mapping distribution of groundwater quality parameters and results clearly reveal that the water quality level is good with respect to the measured quality parameters. The overall groundwater quality map produced clearly reveals groundwater suitability for drinking purpose. Such a map developed using WQI and GIS can be a useful practical tool for easy understanding by water managers, policy makers and even concerned communities in taking strategic decisions towards sustainable use and management of groundwater resources in the area.

\section{References}

Adelana, S. M. A. (2004). Water pollution by Nitrate in a Weathered/Fractured Basement Rock Aquifer: The case of Offa area, West central Nigeria.Research Basins and Hydrological Planning: Proceedings of the International Conference, Hefei/Anhui, China, 22-31 March 2004, CRC Press,

Akan, J. C., Ogugbuaja, V. O., Abdulrahman, F. I. and Ayodele, J. T. (2009). Pollutant Levels in Effluent Samples from Tanneries and Textiles of Kano Industrial Areas, Nigeria.Global Journal of Pure and Applied Sciences, 15, pp. 3-4.

Akujieze, C. N., Coker, S. and Oteze, G. (2003). Groundwater in Nigeria-a millennium experience-distribution, practice, problems and solutions. Hydrogeology Journal, 11(2), pp. 259-274.

Allamin, I. A. (2015). Physicochemical and Bacteriological Analysis of Well Water in Kaduna Metropolis, Kaduna State. Open Access Library Journal, Scientific Research Publishing, 2(6), pp. 1-8. 
Al-Musawi, N. O., Al-Obaidi, S. K. and Al-Rubaie, F. M. (2018). Evaluating Water Quality Index of Al Hammar Marsh, South of Iraq with the Application of GIS Technique. Journal of Engineering Science and Technology, 13(12), pp. 4118-4130.

Ambiga, K. (2016). Assessment of Groundwater Quality Index Using GIS at Tirupathi, India”, International Research Journal of Engineering and Technology (IRJET), 3(2), pp. $552-564$.

APHA (2005). Standard Methods for the Examination of Water and Wastewater. American Public Health Association (APHA): Washington, DC, USA.

Bairu, A., Tadesse, N. and Amare, S. (2013). Use of geographic information system and water quality index to assess suitability of groundwater quality for drinking purposes in Hewane areas, Tigray, Northern Ethiopia. Ethiopian Journal of Environmental Studies and Management, 6(2), pp. 110-123.

Bichi, M. H. (2000). Surface Water Quality in the Kano industrial Environment. Issues in Land Administration and Development in Northern Nigeria, Proceedings of the National Workshop on Land Administration and Development in Northern Nigeria, Department of Geography Bayero University, Kano, pp. 305-313.

Chapman, D. V. (1996), Water Quality Assessments: A Guide to the Use of Biota, Sediments and Water in Environmental Monitoring, CRC Press.

Chaterjee, C. and Raziuddin, M. (2002). Determination of Water Quality Index (WQI) of a degraded river in Asanol Industrial area, Raniganj, Burdwan, West Bengal. Nature Environment and Pollution Technology, 2, pp. 181-189.

Cude, C. G. (2001). Oregon Water Quality Index a tool for Evaluating Water Quality Management Effectiveness 1. JAWRA Journal of the American Water Resources Association, Wiley Online Library, 37(1), pp. 125-137.

Dan'azumi, S. and Bichi, M. H. (2010), "Industrial pollution and Implication on Source of Water Supply in Kano, Nigeria", International Journal of Engineering \& Technology, 10(1), pp. 101-109.

Dike, N. I., Ezealor, A. U., Oniye, S. J. and Ajibola, V. O. (2013). Pollution Studies of River Jakara in Kano Nigeria, using Selected Physicochemical Parameters. International Journal of Research in Environmental Science and Technology, 3(4), pp. 122-129.

DIVA-GIS (2019): http://www.divagis.com retrieved in 2019

Egwuonwu, G. N., Olabode, V. O., Bukar, P. H., Okolo, V. N. and Odunze, A. C. (2011). Characterization of Topsoil and Groundwater at Leather industrial area, Challawa, Kano, Northern Nigeria. The Pacific J. Sci. Technol, 12(1), pp. 628-641.

Galadima, A., Garba, Z. N., Leke, L., Almustapha, M. N. and Adam, I. K. (2011). Domestic water pollution among Local Communities in Nigeria-causes and consequences. European Journal of Scientific Research, 52(4), pp. 592-603. 
Griggs, D., Stafford-Smith, M., Gaffney, O., Rockström, J., Öhman, M. C., Shyamsundar, P., Steffen, W., et al. (2013). Policy: Sustainable Development Goals for People and Planet. Nature, 495(7441), 305p.

Hamza, S. M., Ahsan, A., Imteaz, M. A., Mohammad, T. A., Ghazali, A. H. and Shariff, A. R. M. (2017). Assessment of Spatial Relationship between Groundwater pollution Vulnerability and Quality Indices in Kano, Nigeria. Arabian Journal of Geosciences, 10(7), $168 \mathrm{p}$.

Hemamalini, J., Mudgal, B. and Sophia, J. D. (2017). Effects of Domestic and Industrial Effluent Discharges into the Lake and their Impact on the Drinking Water in Pandravedu Village, Tamil Nadu, India. Global Nest Journal, 19(2), pp. 225-231.

Jasmin, I. and Mallikarjuna, P. (2014). Physicochemical Quality Evaluation of Groundwater and Development of Drinking Water Quality Index for Araniar River Basin, Tamil Nadu, India”, Environmental Monitoring and Assessment, 186(2), pp. 935-948.

Khan, N., Hussain, S. T., Hussain, J., Jamila, N., Ahmed, S., Ullah, R., Ullah, Z., et al. (2012). Physiochemical Evaluation of the Drinking Water Sources from District Kohat, Khyber Pakhtunkhwa, Pakistan. International Journal of Water Resources and Environmental Engineering, Academic Journals, 4(10), pp. 302-313.

Khan, S., Shahnaz, M., Jehan, N., Rehman, S., Shah, M. T. and Din, I. (2013). Drinking Water Quality and Human Health Risk in Charsadda District, Pakistan. Journal of Cleaner Production, Elsevier, 60, pp. 93-101.

Krishan, G., Singh, S., Gurjar, S., Kumar, C. P. and Ghosh, N. C. (2016). Water Quality Assessment in terms of Water Quality Index (WQI) using GIS in Ballia District, Uttar Pradesh, India. J Environ Anal Toxicol, 6(366), pp. 2161-0525.

Manap, M. A., Sulaiman, W. N. A., Ramli, M. F., Pradhan, B. and Surip, N. (2013). A knowledge-Driven GIS Modeling Technique for Groundwater Potential Mapping at the Upper Langat Basin, Malaysia. Arabian Journal of Geosciences, 6(5), pp. 1621-1637.

Mitra, B. K., Sasaki, C. and Keijirou, E. (2006). Spatial and Temporal Variation of Ground water Quality in sand dune area of aomori prefecture in Japan. 2006 ASAE Annual Meeting, American Society of Agricultural and Biological Engineers.

Panigrahi, T., Das, K. K., Dey, B. S. and Panda, R. B. (2012). Assessment of Water Quality of river Sono, Balasore. International Journal Environmental Science, 3(1), pp. 49-56.

Pradhan, B. (2009). Groundwater Potential Zonation for Basaltic Watersheds using Satellite remote sensing data and GIS techniques. Open Geosciences, 1(1), pp. 120-129.

Pritchard, M., Mkandawire, T. and O'neill, J. G. (2008). Assessment of Groundwater Quality in shallow wells within the Southern Districts of Malawi. Physics and Chemistry of the Earth, Parts A/B/C, 33(8-13), pp. 812-823.

Roy, S., Hazra, S., Chanda, A. and Das, S. (2020). Assessment of Groundwater Potential zones using multi-criteria decision-making technique: a micro-level case study from red and lateritic zone (RLZ) of West Bengal, India. Sustainable Water Resources Management, Springer, 6(1), pp. 1-14. 
Sharma, N. D. and Patel, J. N. (2010). Evaluation of Groundwater Quality Index of the urban segments of Surat City, India. Int J Geol, 4(1), pp. 1-4.

Shirazi, S. M., Imran, H. M. and Akib, S. (2012). GIS-Based DRASTIC method for Groundwater Vulnerability Assessment: a review. Journal of Risk Research, 15(8), pp. 9911011.

Thirumalaivasan, D., Karmegam, M. and Venugopal, K. (2003). AHP-DRASTIC: Software for Specific Aquifer Vulnerability Assessment Using DRASTIC model and GIS. Environmental Modelling \& Software, 18(7), pp. 645-656.

Varnosfaderany, M. N., Mirghaffary, N., Ebrahimi, E. and Soffianian, A. (2009). Water Quality Assessment in an arid Region using a Water Quality Index. Water Science and Technology, 60(9), pp. 2319-2327.

WHO (2011). Guidelines for Drinking-Water Quality. WHO Chronicle, 38(4), pp. 104-8.

World Health Organization (2017). UN-Water Global Analysis and Assessment of Sanitation and Drinking-water (GLAAS) 2017 report: Financing Universal Water, Sanitation and Hygiene under the Sustainable Development Goals.

Zingoni, E., Love, D., Magadza, C., Moyce, W. and Musiwa, K. (2005). Effects of a semiformal urban Settlement on Groundwater Quality: Epworth (Zimbabwe): Case study and groundwater quality zoning. Physics and Chemistry of the Earth, Parts $A / B / C, 30(11)$, pp. 680-688.

\section{Cite this article as:}

Saidu A. A., Danazumi S. and Hamza S. M. 2021. Assessment of Groundwater Quality Using Water Quality Index and Geographic Information System in Kumbotso Local Government Area, Kano State, Nigeria. Nigerian Journal of Environmental Sciences and Technology, 5(2), pp. 569-581. https://doi.org/10.36263/nijest.2021.02.0318 